\title{
Perspective of Cikahuripan Villagers on Traditional Health Service Provisions in Government Regulation No. 103 Year 2014
}

\author{
Hashfi Khairuddin, ${ }^{1}$ Rizal Chaidir, ${ }^{2}$ Deni Kurniadi Sunjaya ${ }^{3}$ \\ ${ }^{1}$ Faculty of Medicine Universitas Padjadjaran, Indonesia, ${ }^{2}$ Department of Orthopedics \\ and Traumatology Faculty of Medicine Universitas Padjadjaran/Dr. Hasan Sadikin \\ General Hospital Bandung, Indonesia, ${ }^{3}$ Department of Public Health Faculty of Medicine \\ Universitas Padjadjaran, Indonesia
}

\section{Abstract}

Background: Traditional health service is one of the health services that is still currently used in Indonesia, especially in rural communities. The government has been regulating these services since 2014. Despite its long existence, there is a recent increase of potential regulation violation among traditional health service providers. This study aimed to explore the perspective of the Cikahuripan Villagers on Government Regulation on traditional health services.

Methods: This was a qualitative study using in-depth interviews and direct observations on traditional health services in Cikahuripan Village. Sixteen informants consisting of 8 villagers who met the inclusion criteria and another 8 informants in the triangulation negative case analysis, member checking, peer debriefing, and observation was involved.

Result: There were two different perspectives in the community on traditional health service provisions in the Government Regulation. Supporters of the regulation believed that the regulation would make traditional health services more responsive and safer, which would improve service quality and health benefits as well as imposing effective sanctions. In contrast, the opposition believed that regulations were too late, would make the costs for licensing expensive, and too complicated.

Conclusions: There are two different public perspectives on the regulation of traditional health services, which are supporting and opposing the regulation. It is expected that the local government create a derivative of the regulation by making adjustment to the community's situation.

Keywords: Laws, perceptions, regulations, traditional health services

\section{Introduction}

Traditional health services have long been rooted in individuals in the household, especially starting in the $2^{\text {nd }}$ century to the $19^{\text {th }}$ century. In the Batupuaro sub-district, Baubau city, traditional health services have been started since 1986. In the Dayak tribe, traditional medicine itself stands in line with the Dayak tribe's existence. Whereas the Muna tribe, Wakontu Village, Wadaga Subdistrict, West Muna Regency, said that traditional medicine had existed before medical practices. ${ }^{1-4}$

The Indonesian government has issued a Government Regulation Number 103 in 2014 concerning the Traditional Health Services, which regulates the implementation of traditional health services, including responsibilities, central and local government authorities, types of traditional health services, traditional health service procedures, resources, research and development, publication and advertising, community empowerment, funding, guidance, and supervision as well as an administrative penalty. ${ }^{5}$

The obligation to obtain permission and intervention regulation can potentially disrupt the course of traditional health services that have been trusted by the community long before the application of the regulation. This is supported by a previous study showing that the Indonesian Traditional Herbal Medicine Association (ASPETRI) is not ready in the implementation of Government Regulation Number $103 / 2014 .{ }^{6}$ Interestingly, there are no

Correspondence: Hashfi Khairuddin, Faculty of Medicine Universitas Padjadjaran, Jalan Raya Bandung-Sumedang Km. 21, Jatinangor, Sumedang, Indonesia, Email: hasshfi@gmail.com. 
data on the total number of traditional health services in West Bandung or West Java, who have permission and opinion on this matter.

The community's demands for traditional medicine is about $20 \%$ of Indonesia's total population. Thus, the implementation of regulation could bring up different opinions in society. On one side, the government has created rules for safety and comfort in utilizing traditional health services. On the other hand, this regulation is enough to restrict the community's traditional health services, therefore, the differences in perception can occur in the community. ${ }^{7}$

Previous studies have not yet analyzed the perception of the community as a user when Government Regulation Number 103/2014 is started. The purpose of this study was to explore the community's perspectives in Cikahuripan Village, Lembang, West Bandung, regarding Government Regulation Number $103 / 2014$, regulations that govern traditional health services.

\section{Methods}

This research was conducted in Cikahuripan Village from August to October 2019 using a qualitative research design with grounded theory to explore the processes, activities, and events experienced by respondents. The sampling method used in this study was a theoretical sampling, that was not referring to the number of samples, but the amount of data obtained from the respondents until the data saturation had been reached and therefore aimed to create a theory. ${ }^{8}$

The inclusion criteria in this study were residents of West Bandung Regency who lived in Cikahuripan village, had used traditional health services, and agreed to become research subjects. The exclusion criteria in this study were people who had limited senses such as blind, impaired hearing, impaired speech, and the mentally disabled.

In determining the respondents, a purposive sampling technique was conducted by visiting and conducting in-depth interviews with one of the traditional health services in Cikahuripan Village and asking respondents who had used traditional health services in the village. Next, the snowball sampling technique was performed to get other respondents until the saturation of the data was reached. Saturation was achieved when eight respondents who entered as inclusion criteria were interviewed thoroughly.

Furthermore, a negative case analysis was conducted to increase trustworthiness in this study, by interviewing the Cikahuripan villagers who had never used traditional health services as triangulation respondents. Eight triangulation respondents were interviewed thoroughly in this study until achieving saturation.

The method in this study was in-depth interviews using open-ended questions, therefore, the informant could tell the widest possible extent about his/her experiences and perspectives. First, they were interviewed by asking their health-seeking behavior to determine whether they had used traditional health services. Respondents were given a short explanation about the regulations governing traditional health services PP No. 103/2014, and their perspectives regarding these regulations were explored. The researcher also checked the informants who were interviewed. Source triangulation with negative case analysis, observation, and member checking was done to increase trust worthiness.

The researcher also had made observations to strengthen the theory that would be formed. The observation was carried out by going directly to one of the traditional health services available in Cikahuripan Village, then asking and seeing firsthand how the traditional health care methods were carried out.

In brief, the results of each interview were transcribed into text form. Then, data reduction and analysis were conducted to select and focus on the gross data that appeared in the field. Furthermore, we conducted data encoding, i.e., breaking the data and rearranging the data in the form of words or phrases as representatives of the data fractions. Categorization, the results of data coding, were grouped into homogeneous categories for the process of interpretation, then the preparation of themes, namely by grouping categories in a collection of categories that were considered homogeneous. Furthermore, content analysis, the process of data interpretation, in the form of material categorization based on related topics were conducted. Thick description, interpretation of the data in the form of strong and deep descriptions and narratives expressed were performed and then analyzing the content analysis, analyzing the results from the perspective of the community. ${ }^{9}$

Several perspectives from the first responder (R1) to the sixteenth (R16) were quoted and referred with codes assigned to them from R1 to R16. R1-R8 was respondents who had used traditional health services, while 
Table Content Analysis of Public Perceptions of Traditional Health Services Regulation

\begin{tabular}{ll}
\hline \multicolumn{1}{c}{ PRO } & CONS \\
\hline Accountability & Late Enactment \\
Security & Increased Cost \\
Quality Increase & Increased Complexity \\
Health Benefit Increase & Ignorance \\
Sanctions on Violator & Demand Mismatch \\
\hline
\end{tabular}

R9-R16 was respondents who had never used traditional health services, and designated as a triangulation. This research had been approved by the Research Ethics Committee Universitas Padjadjaran, with the registration number of 902/UN6.KEP/EC/2019

\section{Results}

The respondents included consisted of men and women, aged 17-65 years, education level were varied between elementary school graduates to Diploma. The jobs of the respondents were farmers, ranchers and milking workers, students, hotel employees, traders, market workers, construction workers, parking attendants, housewives, teachers, and traditional health workers.

Public opinions of violations in traditional health services according to government regulation number 103/2014 was polarized into two sides. There was a support for the regulation, but there was also an opposition to the regulation as shown in Table 1.

Cikahuripan villagers assumed that regulations governing traditional health services were a form of accountability for traditional health services in providing health services. Like R7 said,

"The regulations intend to make the traditional health services more accountable so that they are more careful, and there is a potential threat of being punished by the law."

All forms of actions taken by traditional health services could be justified legally. Regulation in traditional health services was considered to increase security in traditional health services in conducting services. This showed the community's sense of insecurity in utilizing traditional health services at this time, so that this regulation was expected to increase the security of traditional health services. R5 also said,

"People like us now look for traditional health services. We do not look for the best, but we are looking for the official ones, so they should not be careless at least. Our leg is important to support life and daily activities."

From some opinions, it was seen that the community was very concerned about the safety of traditional health services and that security for consumers was also guaranteed. The community also had the opinion that if the government prohibited traditional health services, the community would be more careful. Regulations were considered to increase the security of traditional health services, thereby increasing public confidence in using traditional health services.

The public believed that with regulations, traditional health services would improve the quality of their services. As said by R5,

"Compared to the traditional health services that are not licensed, the provided treatment is better in the licensed ones."

R5 was one of the respondents who had used traditional health services that had followed government regulations and felt that the health services provided were indeed better.

With the regulation, traditional health services were considered to provide more health benefits than before. R5 believed that, "Traditional health services is becoming official. Cooperation is also maintained with the local health department and Public Health Center (Pusat Kesehatan Mayarakat, Puskesmas). Even if we use traditional medicine, we also need drugs, antibiotics, anti-pruritic, as well as the prohibition of some foods. Compared to those who are not licensed, the healing process is faster in those who are licensed."

With the regulation, it was also considered by the public that there were sanctions for every violator of the regulation. As said by R1, "Now, there are sanctions for traditional birth attendants (traditional health services), so they are no longer allowed."

This was considered reasonable by the community as protection for users of traditional health services. However, the community also considered that there was a 
delay in the enactment of this regulation. R2 said,

"It can be said that the rules are late. Why was it not enacted earlier? These services have been around for a long time, and there are already many patients using it."

The community considered that the traditional health services that already existed could not be blamed because they had been around for a long time and were rooted culturally in the community.

The regulation was also perceived to cause traditional health services more expensive, contradicting the principles of traditional health services, which was low cost. R9 said, "If there were an obligation to use a permit, I am afraid it would be expensive. It is just not fair for the poor."

This regulation was considered by the community to only make the traditional health service system complicated. As said by R4,

"If we comply with the regulations, we must use permits. It is rather complicated. I do not agree."

Whereas the formation of traditional health services was based on the needs of the community and the capabilities of traditional health service providers, which would be discussed next.

Community needs and the ability of traditional health service providers formed the basis for the formation of traditional health services, as said by R16,

"When it comes to regulations, here we (traditional health services) only help, we do not even advertise. If anyone needs help, how can we reject it?"

The regulation was considered not friendly to traditional health services, which were formed due to community needs. Due to regulations that were considered unfriendly by the people of Cikahuripan village, many people were ignoring these regulations. As said by R3,

"Even though traditional health services violate regulations, people still want to go there because they already believe they have experienced it themselves."

In addition, researchers also made observations of the only traditional health service in Cikahuripan Village, resulting in that this traditional health service had no permission from the government. The service did not put up advertisements or signposts and only served if there was a need from the community. The type of treatment was rehabilitative, including massage and giving water accompanied by prayer for patients with broken bones. The services provided were in accordance with the regulations, although they had no permit according to the regulations

\section{Discussion}

There are two perceptions of Cikahuripan villagers on regulations governing traditional health services. There is support for the regulation and there is opposition against the regulation, each with different reasons. The existence and application of traditional health services are a necessity of the community. As in the Dayak community, traditional medicine is currently still used in irrational diseases that never heal. In the community, traditional health services are considered effective in curing various diseases and eventually become a necessity for the community. The Dayaks believe that before or after seeing a doctor or health worker, they must seek alternative medicine or traditional health services. ${ }^{3}$ In GayoLues Regency, Aceh Province, traditional health services are believed to be able to increase the health and strength of the body. The benefits match up the expectations of the Gayo people. It also illustrates that traditional health services have become the needs of the community. ${ }^{10}$ The people of Lede Village, Tilabu Regency, and North Maluku Province also feel better after the treatment of traditional health services. The service and recovery rate of traditional health services is felt far better. This makes Lede villagers trust and visits traditional health services more often compared to conventional health services. This illustrates that traditional health services are a necessity for the people of Lede Village ${ }^{11}$ Furthermore, the people of TelluSiattinge, Bone Regency, South Sulawesi, strongly believes in traditional health services to treat various diseases for generations. It is this belief that makes the community seeks traditional health services so that traditional health services become the community's needs. ${ }^{13}$

As in West Java, research conducted in rural communities shows that public confidence in traditional medicine is still high. Traditional medicine does not do a lot of information literacy in carrying out its practice. However, long-standing community trust makes traditional health services an inseparable community needs. ${ }^{12}$ In our research, it has been proven that traditional health services have become the community's needs. That is the reason why people do not agree with the existing traditional health service regulations, due to the practice limitation of 
traditional health services. This is supported by several studies that prove that traditional health services have become an integral part of the community and are a necessity for the community in seeking treatment. If this regulation has been implemented in all regions of Indonesia, it can be predicted that there will be many rejections from various groups of people regarding this regulation.

The interview results of researchers on traditional health services in the village of Cikahuripan have shown the unpreparedness of traditional health workers to implement this regulation. The traditional practitioner considers that its existence is only to meet the needs of the people who often ask them for help. This is also supported by the Indonesian Traditional Herbal Medicine Association (ASPETRI), as it is not ready to implement this regulation. ${ }^{6}$

From the economical perspective of the community, traditional health services are preferred because they are cheaper than conventional health services. These are found in studies conducted in various places such as in Lede Village, PulauTalibu Regency, North Maluku, also in TelluSiattinge, Bone Regency, South Sulawesi. The people tend to choose traditional health services because it is more affordable, or they never ask for wages or fees in providing their services. ${ }^{11,13}$ In our study people show rejection of the existence of regulation due to economic reasons. Traditional health services that are known to be cheap and never charge fees are afraid to lose their economic value or become more expensive and even set costs if they follow this regulation.

In terms of the responsibility of traditional health services, research conducted in West Java shows that most traditional health services usually claim their healing success from God's gift. This makes the customer and the government cannot do anything if there are cases that are detrimental. ${ }^{12}$ This is in line with the expectations of Cikahuripan villagers with the enactment of this regulation. This regulation is expected by the community to be one of the solutions so that traditional health services can be more responsible for what they have done and get appropriate sanctions if violations occur in practice. However, research conducted on rural communities in the West Java states that the dissemination of information from West Java provincial government for traditional medicine has been quite successful. This is different from the perspective of the community and health services in the village of Cikahuripan. They do not know anything about the rules or appeals in the use of traditional health services. The researchers must briefly explain the related laws in advance so that the community can give their perceptions regarding the regulation. Insufficient dissemination of comprehensive information was found in this study. ${ }^{12}$

A study in West Java concerning regulations governing traditional health services showed that the community welcomed this regulation in contrast with the previous study; our study has found that the people of Cikahuripan village have two different perceptions; support and reject the regulation. ${ }^{12}$ In the national health system, the government is responsible as a supervisor or steward of the public services. To carry out the stewardship function of government in traditional health services, they enact laws to regulate traditional health services. As an instrument, the permit takes the role as a guide, or to drive citizens' behavior. Licensing is also intended to provide guidance, regulation, control, and supervision of traditional health services. Permission is issued by the authorities as an instrument to influence relations with citizens in order to be willing to follow the ways they advocate in order to achieve concrete goals. ${ }^{14,15}$ To provide that function, the government enacts the Government Regulation Number 103/2014 on traditional health services, which is expected to increase the quality of traditional health services along with decreasing side effects that are medically irresponsible. ${ }^{16}$ This is in accordance with part of the community that supports the regulation of traditional health services, in which the regulation is believed to improve the quality of services, health benefits, and security of traditional health services. This regulation is also believed to help the accountability of traditional health services.

With the regulation, if a violation is committed by a traditional health person or a traditional health worker, then the patient can report it to the Health Service, then public health office will conduct a sudden inspection to the alternative medicine and directly ask the therapist. However, it does not directly guarantee if alternative medicine will fulfill its responsibilities as a business actor that harms consumers. Patients can report the violation directly to the police if they feel they are victims of malpractice or neglect of alternative healers. ${ }^{17}$ This is in accordance with the perception of the community that considers that regulations governing traditional health 
services will impose sanctions on traditional health services that violate them.

This study was limited to the village of Cikahuripan, Lembang Subdistrict, West Bandung Regency. However, the data was derived from facts in the field.

To conclude, there are two different perspectives in the community of villagers of Cikahuripan village regarding the regulation $13 / 2014$; some who support and others are opposed the traditional health services. Supporters of the regulation believe that the regulation would make traditional health services more responsive, safer, improving service quality, increase health benefits, and impose effective sanctions, whereas opposition of the regulation believes that regulations would make the costs for licensing expensive, and too complicated. Some even do not care about the regulations because they believed that traditional health services have always become a part of the community and therefore, cannot be regulated.

\section{References}

1. Triratnawati A. Pengobatan tradisional, upaya meminimalkan biaya kesehatan masyarakat desa di jawa. Jurnal Manajemen Pelayanan Kesehatan. 2010;13(2):69-73.

2. Wahid WOL, Basri LOA. Sejarah pengobatan tradisional orang Buton di Kecamatan Batupoaro Kota Baubau: 1986 - 2016. Journal Idea Of History. 2018;1(1):49-62.

3. Asmawati, Hartati Z, Emawati. Makna pengobatan tradisional Badewah Suku Dayak bagi masyarakat muslim di Kalimantan Tengah. Jurnal Studi AgamaAgama. 2018;8(1):82-115.

4. Harwati J, Niampe L, Wardani AK. Tradisi pengobatan Pamole pada Suku Muna Desa Wakontu Kec. Wadaga Kabupaten Muna Barat. Jurnal Kelisanan Sastra dan Budaya. 2018;1(2):93-9.

5. Presiden Republik Indonesia. Peraturan Pemerintah Republik Indonesia Nomor 103 Tahun 2014 tentang Pelayanan Kesehatan Tradisional. Jakarta: Pemerintah Republik Indonesia; 2014

6. Murpratiwi R, Jati SP, Suparwati A. Analisis kesiapan asosiasi pengobat tradisional terhadap rencana implementasi Peraturan Pemerintah Nomor 103 Tahun 2014 tentang Pelayanan Kesehatan Tradisional di kota Semarang. Jurnal Kesehatan
Masyarakat. 2016;4(1):65-75.

7. Badan Pusat Statistik Indonesia. Persentase penduduk yang mempunyai keluhan kesehatan dan penggunaan obat menurut Provinsi dan Jenis Kelamin [Internet]. Jakarta: Badan Pusat Statistik Indonesia; 2016. [cited 2020 January 4] Available from: https://www.bps. go.id/statictable/2012/05/02/1619/ persentase-penduduk-yang-mempunyaikeluhan-kesehatan-dan-penggunaanobat-menurut-provinsi-dan-jeniskelamin-2009-2014.html

8. Qureshi HA. Theoretical sampling in qualitative research: a multi-layered nested sampling scheme. International Journal of Contemporary Research and Review. 2018;9(8):20218-22.

9. Cresswell JW, Cresswell JD. Research design: qualitative, quantitative, and mixed methods approaches. 5th Ed. California: SAGE Publication; 2017. p. 232-62.

10. Fitrianti Y, Angkasawati TJ. Pengobatan tradisional Gayo untuk ibu nifas. Buletin Penelitian Sistem Kesehatan. 2015;18(2):111-9.

11. Rismawati, Sifatu WO. Pengobatan tradisional pada masyarakat di Desa Lede Kabupaten Pulau Taliabu Provinsi Malluku Utara. Etnoreflika. 2017;6(3):249-56.

12. Rahman MT, Sulthonie AA, Solihin. "Sosiologi informasi pengobatan tradisional religius" kajian di masyarakat perdesaan Jawa Barat. Jurnal Studi Agama dan Masyarakat. 2018;14(2):100-11.

13. Adiwijaya AE. Eksistensi pengobatan tradisional di Tellusiattinge. Jurnal Kajian Sosial dan Budaya. 2019;3(2):10-8.

14. Jefri R. Teori Stewardship dan Good Governance. Economics Bosowa Journal. 2018;4(3):14-28.

15. Fathoni N, Tisnanta S. Konstruksi makna izin sebagai instrumen pengendalian versus kebijakan kemudahan investasi di provinsi lampung. Jurnal Hukum Peratun. 2018;1(1):79-100.

16. Kartika D. Pelayanan kesehatan tradisional dan perlindungan hukum bagi pasien. Soepra Jurnal Hukum Kesehatan. 2016;2(1):1-16.

17. Kamal U. Konstruksi perlindungan konsumen jasa pengobatan alternatif (Studi kasus di kota Semarang). Journal of Private and Commercial Law. 2017;1(1):69-84. 